Linguistik Terapan 17 (3) (2020): 225-234.

Jurnal Linguistik Terapan Pascasarjana

Available online

http://jurnal.unimed.ac.id/2019/index.php/JLT-Unimed

\title{
THE INTERACTION OF SOCIAL STRATIFICATION AND KARONESE REGISTER IN GIVING PEDAH PEDAH PERJABUN
}

\author{
Elkana Putra Tarigan \\ Amrin Saragih \\ Siti Aisyah Ginting \\ English Aplied Linguistic Program \\ Postgraduate Program-Universitas Negeri Medan
}

Diterima September 2020; Disetujui Oktober 2020; Dipublikasikan Desember 2020

\begin{abstract}
Indonesia was well known for the variety of tribes, traditional languages, society and culture. It triggered to conduct this research that concerned to social stratification and Karonese register in giving pedah pedah perjabun. The problem of this research was how far the Karonese register change in this modern era or whether there were any differences among society group in Karonese traditional wedding ceremony. Based on this problem, this research aimed to 1) investigate the types of social stratification in traditional wedding ceremony of Karonese, 2) describe the reflections of social stratification toward the Karonese register, and 3) explain Karonese register in traditional wedding ceremony. This research was conducted by using descriptive qualitative design. The data were taken from Karonese register in traditional wedding ceremony and the source of data was Karonese native speaker who involved in traditional wedding ceremony. This research showed that 1) the interaction of Karonese society in traditional wedding ceremony stratifies Karonese people into four divisions. They are kalimbubu and anak beru that categorized as closed social stratification and sembuyak and teman meriah that categorized as opened social stratification, 2) social stratification were reflected through the differences and similarity form of register .Kallimbubu and anakberu used formal register as the most dominant regiser while sembuyak and anak beru used consultative register as the most dominant, and 3) the cause of Karonese register in traditional wedding ceremony was caused by register with reference to field that covered factor of arena and register with reference to tenor that cover formality and status.

Keywords: Karonese Register, Pedah Pedah Perjabun; Social Stratification

How to Cite: Putra Tarigan, Elkana. (2020). The Interaction of Social Stratification and Karonese Register in Giving Pedah Pedah Perjabun. Jurnal Linguistik TerapanPascasarjana Unimed. 17 (3) : 225-234.
\end{abstract}




\section{INTRODUCTION}

There is no language without society and vice versa. Human beings always use language to make interaction among them. Robert (2008) explains that language is the system of speech by which human being communicate with another. Moreover, people can interact with different people in other place, country, and continent and so on. They use spoken and written language in the daily life to facilitate in communication. Wardhaugh (2000) the relationship between language and society with the goal of being a better understanding of the structure of language and how language functions in communication and sociology will be discovered how social can be better understood through the study of language. In establishing a social interaction, people tend to use their own languages based on their purposes or using.

Society is stratified, for example there are strata in society with reference to certain criteria, and language is correspondingly stratified. Society can be stratified in terms of socio economic status as those belonging to working class, middles class and high class. In accordance with stratification, language also has variations, such as variation belonging to the language of the working class, middle class and high class people. Christopher (2013) social stratification is a society's categorization of people into socioeconomic strata, based upon their occupation, income, wealth, social status, and derived power ( social and political). It is the relative social position of persons within a social group, category, and geographic region and social unit. It refers to a system by which a society ranks categories of people in hierarchy.

Karonese people habitually use their own dialect when they have interaction with people different dialect and they have still understand each other even the variation of Karonese language. Indeed, this research explores the variety of Karonese language with reference to the use of language by members of the society in giving pedah pedah perjabun. It is a sacral moment in traditional wedding ceremony of Karonese where family member of bride and groom give some valuable advices.

Karonese is well known of philosophy of life, merga silima, tutur si waloh, rakut sitelu. Merga silima depicts that Karonese Society has five clans or family name. Tutur siwaloh refers to eight kinship terms of Karonese and Rakut Sitelumeans three groups of society that occurs through parentage, sibling relationship and marriage. Sembiring (2016) states that Karonese society has principle of Mehamat man kalimbubu, metenget man senina ras metami man anak beru. In other words, Kalimbubu is considered as visible god (those who must be honored), senina is those who has same clan and should be careful and wise to 
those of their same clan. Anakberu is those who "serve" and kalimbubu "be served ". This philosophy leads to social stratification occurs in Karo people. It is the grounded phenomenon that stimulates to conduct this research about social stratification and Karonese register in giving pedah pedah perjabun.

Each group in traditional wedding ceremony of Karonese should speak formally, politely and well, since marriage is one of sacred events for Karo people. Nowadays, whether they still speak the same manner or whether there is a change in the way they speak. The following data shows some utterances of Karonese language in wedding traditional ceremony.

Kalimbubu : ......man bre bre kami,,,.ibas doni enda, labo banci kerina bagi sura suranta, adi kalak India ngatakensa, korenge ne pe tahe.... (.... for my beloved nephew....we cannot fulfill all of our wishes like India language korenge ne pe tahe)

Sembuyak: ....duana kena nak ku ras permen......ula kena erlumba lumba nipak bola, mis out kari bola e......(both my son and daughter in law....do not hurry to kick the ball, it can be out...)

Anakberu: .....nak ku...bru biring....adi enggo enjabuken bana, ula lit ACC (anceng, cian, cikurak) bas kam....(my lovely daughter...if you have got married, do not be trouble maker, envious one and gossiper)

It seems obviously that there are some slang in that utterances. Actually, "korenge ne pe tahe" is not real India language, it is used as a joke. "out" is derived from English while " $A C C$ " is abbreviation of group of gossiper. Other words, they speak more casual and less formal. Therefore, the researcher wants to conduct this research to observe how far the registers change in this modern era or whether there are any differences among society group in traditional wedding ceremony. In relation to the problems of studies, the objectives of this analysis are, to investigate the socialstratifications in the Karo society, to describe the reflections of social stratification toward the Karonese register, and to explain register in the Karonese speech community.

\section{METHOD}

This study was conducted by using descriptive qualitative design. The data of this research were the sentences of Karonese language in Tanah Karo uttered by Karonese people in traditional wedding ceremony. That register was specified in giving pedah pedah perjabun by family members of bride and groom The sources of the data in this study were 
the subjects, Karo native speaker who involve in traditional wedding ceremonies of Karonese The data of this study were collected by applying procedure proposed by Miles, Saldana and Huberman (2014). First, the researcher did some preparation or observation before conducting the research such as preparing the tools needed, list of data informant, the instrument of data, and approaching the subject. In this case, it was performed by collecting Compact Disk (CD) of traditional wedding ceremony of Karonese.

It was focused on event of giving pedah pedah perjabun. Second, the researcher conducted interview to get the data. As far as the places of data collection were concerned, they were selected in view the concentration of Karonese speakers belonging to different social groups. It was conducted in traditional wedding ceremony of Karonese in CD. In order to get data as natural as possible, the researcher visited Tiganderket district, Tanah Karo to attend the wedding ceremony. Moreover, the researcher's conversation with master ceremony (to determine each group in ceremony) was recorded in natural way. Third, the researcher transcribed and confirmed the data revealed.

\section{FINDINGS AND DISCUSSIONS}

Based on the data analysis, it was found out there are some important findings to be presented. It can be seen in the following table

Table 1. Realization of Karonese Register

\begin{tabular}{|c|c|c|c|c|}
\hline No & Group of Society & $\begin{array}{l}\text { Type of social } \\
\text { Stratification }\end{array}$ & Register & Percentage (\%) \\
\hline \multirow[t]{5}{*}{1} & $\mathrm{~K}$ & $\mathrm{CS}$ & FoR & 75.60 \\
\hline & & & CoR & 20 \\
\hline & & & FrR & 2.85 \\
\hline & & & $\mathrm{CaR}$ & 1.55 \\
\hline & & & $\mathrm{InR}$ & - \\
\hline \multirow[t]{5}{*}{2} & $S$ & $\mathrm{CS}$ & CoR & 47.15 \\
\hline & & & For & 41.10 \\
\hline & & & CrR & 9.80 \\
\hline & & & Inr & 1.95 \\
\hline & & & FrR & - \\
\hline \multirow[t]{5}{*}{3} & A & CS & FoR & 76 \\
\hline & & & FrR & 24 \\
\hline & & & CoR & - \\
\hline & & & $\mathrm{CaR}$ & - \\
\hline & & & InR & - \\
\hline
\end{tabular}




\begin{tabular}{llll}
\hline $4 \mathrm{~T}$ & OS & CoR & 52.9 \\
& FoR & 41.1 \\
& CaR & 6 \\
& CaR & - \\
& InR & - \\
\hline
\end{tabular}

Note

CS : Closed social stratification

OS : Opened social stratification

FrR : Frozen Register

FoR : Formal Register

CoR : Consultative Register

$\mathrm{CaR} \quad$ : Casual Register

InR : Intimate Register

Based on the table above, social stratification and Karonese register appeared in Karonese wedding ceremony when they interact and speak their language in giving pedah pedah perjabun in traditional wedding party. The table shows that among group in social stratification have similarity and differences in Karonese ethnic register that refers to type of registers

The interaction of Karonese society in traditional wedding ceremony stratifies Kaoronese people into different divisions. It shows that there are four divisions or society grouping appear in Karonese speech community. They are kalimbubu, sembuyak, anak beru, and teman meriah. Kalimbubu is the most frequent (33.3\%), anak beru and sembuyak have the same frequency $(28.6 \%)$ and teman meriah has the lowest frequency (9.5\%). Kalimbubu, sembuyak and anakberu are categorized to be closed social stratification due to permanent system of traditional culture of Karonese that cannot be changed, while teman meriah is categorized to be opened social stratification due to impermanent relationship that can be changed.

Social stratifications are reflected through the difference and similarity form of Karonese registers. They are show sentences. The form register of kalimbubu group shows four type of register, formal register is the most frequent (75.60\%), formal register (20\%), frozen register $(2.85 \%)$, casual register $(1.55 \%)$. The form of register in sembuyak group shows that four type registers, consultative register is the most dominant (47.15\%), and formal register $(41.10 \%)$, casual register (9.80\%), intimate register (1.95). The form of register of anak beru shows that two type of register. They are formal register (76\%) and frozen register $(24 \%)$. The form of register of teman meriah shows that three type of register. 
Consultative register is the most dominant (52.9\%), formal (41.2\%) and casual register (6\%). Based on this percentage of each group in Karonese speech community, it was found that closed social stratification (kalimbubu, sembuyak and anak beru) has the most frequent registers are formal and consultative while opened social stratification (teman meriah) has the most frequent register is consultative register.

The cause of Karonese registers in traditional wedding ceremony in giving pedah pedah perjabun is caused by register with reference to field which covers factor of arena. It is marked by institutionalized so that it causes the appearance of lexis about traditional marriage of Karonese. Moreover, it is also caused by register with reference to tenor which covers formality (marked by formal and informal) and status (marked by equal and unequal) so that it causes the difference type of register form among the group of social stratification in Karonese speech community

Language varies with respect to the use of language in the society. Saragih (2014) society may also vary in term of functions done by members of society which means that member of society vary with respect to their activities, for instance what they do in society. This research illuminates the variety of Karonese people with respect to the use of register in giving pedah pedah perjabun. The research finding showed that Karonese society stratifies into four divisions, they are kalimbubu.sembuyak, anakberu and temanmeriah. The basic philosophy life of Karo is rakut sitelu (three bonds that explains the completeness of life). This thing leads the variety of Karonese society or social stratification appears in Karonese speech community. Precisely, it showed that kalimbubu, sembuya kand anakberu are categorized to closed social stratification due to the grouping system based on philosophy of life that cannot be altered. If someone is considered as kalimbubuin community, so she or he will be considered as kalimbubu from generation from generation. On the other hand, temanmeriah is considered as opened social stratification due to it can be altered. Temanmeriah means friends, this relationship does not involve to kinship system of Karonese. This finding of this research is different from Sembiring (2016) who investigated Karonese society is grouped into three parts, kalimbubu, sembuyak, anakberu. These findings merely explain three groping of Karonese society in traditional wedding ceremony.

This research is line with Ginting (2015) that explains giving pedah pedah perjabun is sacred events in traditional wedding ceremony of Karonese so that the language used should be formal. Other words, the Karonese register level should be in frozen and formal register since it is formal setting or situation. This research finding showed that the difference of register used from each division of Karonese speech community in traditional wedding 
ceremony. This finding is different with Subiyan (2016) who found formal and frozen register in ceremony of Larung Semboyono in Trennggelek district, while this research finding deals with formal, consultative, frozen and casual register.

The variety and similarity of type of register from each group of Karonese society are caused by the interactions factors. The interaction of kalimbubu, sembuyak, anakberu and temanmeriah are found that registers or the varieties of lexical items appear in that social activity. It is caused register with reference to field which covers arena or social activity that refers to the location where social activities are formed. It is obviously seen that giving pedah pedah perjabun is sacred thing for Karonese people where each speaker is supposed to advice, pray and wish the bride and the groom luck in their future life. It is line with Saragih (2017) the institutional rules may have effect on kinds or inventories of items to be talked and the ways the items are lexicogrammartically realized. The location has features or characteristics of the institution that sets the activity. In this case, karonese people consider that giving pedah pedah perjabun as the activity in the traditional wedding ceremony that is constrained by the rules of the traditional culture system of Karonese. Hence, it is marked by [ + institutionalized] which causes each group of Karonese society's utterances contain traditional culture terms of Karonese or Karonese register appear in that social activity.

Giving pedah pedah perjabun has been set to bless, advice and pray for the bride and the groom so the occurrence of the interaction should be in formality. The finding of this research shows that each group of Karonese community has difference and similarity register. The register used of kalimbibu, anakberu and temammeriah is line with Saragih (2017) who says that the formal situation consequently requires formal language. In this case, formal register is the most dominant used by kalimbubu and anak beru due to the unequal interaction where kalimbubu is considered as visible god and anak beru as a servant. Sembuyak and temanmeriah use consultative register as the most dominant due to the equal interaction where they are considered as mate so it results more casual register. It is obviously seen that the difference and similarity among the groups. This finding tends to show that the register used by sembuyak and temanmeriah reflects the decline of formality of Karonese language at that social activity where it should be in formality. It is line with Yahya (2016) found that the decline of traditional language which caused by globalization

The interaction of Karonese society indicates status that can be equal or unequal. It appears among of social stratification in that community. Firstly, the interaction of kalimbubu and addressee at that social activity is unequal. Kalimbubu is considered as the highest position even it is called as visible god. Secondly, the interaction of sembuyak and addressee 
is equal. Having family name is equality in social position in Karonese community therefore those who have same family name will be grouped into same seat. Thirdly, the interaction of anak beru and addressee is unequal. Anakberu is assigned as a servant in Karonese social activity. Therefore, mostly their seat will be grouped at the kitchen. Fourthly, the interaction of teman meriah and addressee is equal since they are categorized as best mate in daily life.

The equal and unequal status above supports Sembiring (2016) who found the difference social status of Karonese community (kalimbubu, sembuyak, anakberu) has same speech style to bless, praise, pray and advice the bride and groom. It is due to the life way of Karonese, mehamat man kalimbubu, metenget man sembuyak, metami man anakberu (have a great respect to kalimbubu, being aware to sembuyak, having a great affection to anakberu). While this research finds social status (kalimbubu, sembuyak, anakberuand temanmeriah) have difference and similarity type of register. The unequal status interaction (kalimbubu, anak beru) shows that the most frequent register is formal register while the equal status (sembuyak. Teman meriah) uses the most dominant consultative register.

This research found that social stratification appears in Karonese speech community which restricts difference seat and role among of them in social activity. It is opened and closed social stratification. Opened social stratification (temanmeriah) used the most dominant register is consultative. Closed social stratification (kalimbubu, sembuyak, anakberu) used difference type of register where sembuyak used the most dominant consultative register while kalimbubu and anakberu use the most dominant formal register. As a matter of fact, the type of social stratification does not deal with the type of register used in Karonese speech community. The difference and similarity register used among four groups in Karonese speech community is due to field which refers to socially validated interaction or activity. It shows that the factor of arena causes the appearance of some terms about traditional wedding ceremony of Karonese. Moreover, the difference and similarity type of register is due to tenor which refers to the participants involved in interaction with their relationship. It covers factor of formality and status, where the equal status (sembuyak and temanmeriah) shows the most dominant type of register is consultative and the unequal status (kalimbubu and anakberu) deals with formal register.

\section{CONCLUSIONS}

This study was concerned on the interaction of social stratification and Karonese register in giving pedah pedah perjabun. The interaction of Karonese speech community stratifies society into four groups, namely kalimbubu, sembuyak, anakberu, temanmeriah. 
Therefore, it causes social stratification appears in that community. There are two type of social stratification, teman meriah is categorized to be opened social stratification and kalimbubu, sembuyak and anakberu are categorized to be closed social stratification.

Social stratifications are reflected through the difference and similarity form of Karonese register. Kalimbubu who considered as visible god uses the most dominant type of register is formal register. Sembuyak, those who have same family name use the most dominant type register is consultative register. Anakberu, those who are as servant inKaronese social activity use the most dominant type register is formal register. Teman meriah, those are considered as best mate use the most dominant type of register is consultative register.

Four groups in Karonese speech community, kalimbubu, sembuyak, anakberu, and teman meriah result register in reference terms about traditional wedding of Karonese. It is due to the factor of field which covers arena or social activity in the traditional wedding ceremony. This social activity is institutionalized so that it results register. Moreover, the difference register form among the groups is caused by factor of tenor which covers formality and status. It should result formal register but the appearance of difference status, equal and unequal cause not only formal register but also consultative. The equal status shows the most used register is consultative while the unequal status shows the most used register is formality

\section{REFERENCES}

Ahmad,R. (2014). A Sociolinguistics Investigation of Social Stratification and Linguistics Variation among the Kashmir Speech. Journal of Language Teaching and Research.

Aman, I. ( 2009). Social Variation of Malay Language, Sarawak, Malayisa: A Study on Accent, Identity and Integeration. Gema online Journal of Language Studies

Anderson. (2011). Social Stratification.Oxford University Press.

Bangun, T. (1987). Upacara Perkawinan Masyarakat Karo. Kesain Blanc. Jakarta

Bibier, D. (1994). Sociolinguistics Perspectives on Register. New York: Oxford University Press

Bogdan, R and Biklen, S.(1982). Qualitative Research for education (2 ${ }^{\text {nd }}$ ed).Boston:Allan \& Bacon

Charles, E. (2007). Social Inequality: Forms, Causes, and Consequences. Boston MA, Allyn and Bacon

Fromkin,Hymas, and Rodman. (2007). An Introduction to Language. Boston,MA: Thomson Wadsworth 
Hact and Brown. (1995). Vocabulary, Semantic and Language Education. United States of America: Cambridge University Press

Halliday, M. A. K. (2000). An Introduction Functional Grammar. London: Edward Arnold

Hamdany. (2017). Speech Style Used in the Workplace in 500 Days of Summer Movie. Language Horizon Vol 5 number 1

Hudson,R.A. (1996). Sociolinguistics. UK: Cambridge University Press

Irhana (2017). English Register in Allkop News Article. Journal Ilmu Budaya vol 1

Ginting, S.A. (2015). Structure of Karonese Conversation in the Funeral Ceremony: Case Study in In Indonesia. Asian Social Science Canadian Center of Science and Education

Joss, Martin. (1976). The Style of Five Clocks in Current Topics in Language: Introducing Reading, Nancy Ainworth Jhonson (Ed). Massachusetts: Winthrop Publisher.

Martin,J.R. (1992). English Text System And Structure. Philadelphia: John Benjamins

Persel. (1987). The Recomposition of Social Stratification in Poland. Polish Sociological Review.

Prinst, D. (2014). Adat Karo, Medan: Kongres Kebudayaan Karo

Rahajeng. (2013). Register Dalam Pertunjukan "Reog Nawangsih" di Dusun Surulanang. Unpublished.

Robbert B. (2007). Sociolinguistics Variation Theories, methods, and Applications. Cambridge University

Sapir, E. (1965). Language An Introduction to the Study of Speech. New York,USA: New York University

Saragih,A. (2014). Varinction and Functional Varieties of Language. Medan: The State University of Medan

Saunder.P. (2001). Social Class and Stratification. London and New York. $\quad$ Routledge

Sembiring.M. (2010). Variasi Dilaek Bahasa Karo di Kabupaten Karo, Deli Serdang, dan Langkat. Universitas Sumatera Utara. Medaan

Sembiring,M. (2016). Translating Tutur Si Waloh in Karonese Society into English. Theory and Practice language Studies vol 6. 